\title{
ARCHITEKTURA KOLEGIÓW JEZUICKICH WE WLOSZECH I W RZECZYPOSPOLITEJ DO POLOWY XVII WIEKU - POSZUKIWANIE WZORÓW NA WYBRANYCH PRZYKŁADACH
}

\begin{abstract}
Kiedy w końcu XVI wieku Jezuici rozpoczęli swoją działalność na terenie Rzeczypospolitej tym samym zaczął się proces budowy domów zakonnych Towarzystwa Jezusowego. Samodzielnymi jednostkami organizacyjnymi były fundowane przy wsparciu biskupów i magnatów kolegia, przy których jezuici prowadzili działalność edukacyjną. Architektami pierwszych kolegiów na terenie Rzeczypospolitej byli sprowadzani z Włoch architekci-jezuici. Przenosili oni na grunt Polski włoskie rozwiązania, ale (zgodnie z założeniem akomodacji do miejscowych warunków i potrzeb) dostosowywali owe wzorce tak aby lepiej funkcjonowały w odmiennym otoczeniu. Mimo iż wyraźnie widoczne są podobieństwa, zwłaszcza w ogólnym rozplanowaniu elementów zespołu, w polskich transpozycjach wypracowanych we Włoszech wzorców wyraźne są cechy specyficzne dla tego obszaru.

Porównanie rozwiązań architektonicznych i funkcjonalnych kolegiów Polskich i Włoskich pozwala na określenie jak silny był wpływ lokalnych warunków na ugruntowane wzorce. Odmienne warunki klimatyczne zaowocowały odseparowaniem komunikacji od dziedzińców, a także innym sposobem funkcjonowania tychże. Natomiast uboższe sąsiedztwo kolegiów (zwłaszcza w mniejszych miastach) doprowadziło do znacznej redukcji w dekoracyjnym opracowaniu elewacji. Należy jednak pamiętać że jednym z najsilniejszych elementów kształtujących układ funkcjonalny danego zespołu była konieczność dopasowania się do konkretnej, niepowtarzalnej sytuacji: kształtu działki oraz ukształtowania otaczającej tkanki miejskiej poprzez wykorzystanie istniejących osi i połączeń widokowych. Czyni to każdy obiekt niepowtarzalnym i najlepiej ukazuje filozofię działania zakonu jezuitów.
\end{abstract}

Słowa kluczowe: Towarzystwo Jezusowe, architekci jezuiccy, styl jezuicki, szkoły jezuickie

\section{Wprowadzenie}

Historycy sztuki XIX wieku (szczególnie w Niemczech) wprowadzili pojęcie tzw. stylu jezuickiego (Jesuitenstil), określając tym mianem nazbyt dekora-

\footnotetext{
${ }^{1}$ Klara Kantorowicz, Politechnika Warszawska, Wydział Architektury, ul. Koszykowa 55, 00-659 Warszawa; klarakantorowicz@yahoo.com
} 
cyjny nurt baroku, często graniczący ze złym smakiem [1]. Jednak już od początków XX wieku wielu autorów (między innymi: Francois de Dainville [2], Yvan Christ [3], Pietro Pirri [4], Pierre Moisy [5], Jean Vallery-Radot [6], Richard Bösel [7], Mario Bencivenni [8], Jerzy Paszenda [9], Gauvin Alexander Bailey [10], Evonne Levy [11]) sprzeciwiało się tej koncepcji wskazując na silne zróżnicowanie rozwiązań architektonicznych i stylistycznych na obszarze różnych prowincji jezuickich.

Jezuici sami określali budownictwo wznoszone na potrzeby zakonu jako kształtowane według modus noster - "naszego sposobu". W pewnej mierze usprawiedliwia to błąd XIX-wiecznych badaczy, którzy ukuli sformułowanie: styl jezuicki. Określenie to jednak, patrząc na odmienne rozwiązania stylistyczne zastosowane przez architektów jezuickich w różnych regionach, należy odnieść bardziej do aspektów technicznych, praktycznych i funkcjonalnych budynków wznoszonych na potrzeby Towarzystwa Jezusowego. Modus noster dotyczył zatem bardziej sposobu działania niż kanonu rozwiązań stylistycznych [12], gdyż podstawową zasadą działania zakonu było dostosowanie się do miejscowych warunków, potrzeb i przyzwyczajeń [13]. Ów sposób działania dotyczył jednak nie tylko samego procesu inwestycyjnego i budowlanego ale również sposobu funkcjonowania samych obiektów, czyli ich wewnętrznych układów funkcjonalnych. Mimo próśb prowincjałów nie zostały, ze względu na różnorodność uwarunkowań, wprowadzone do powszechnego użytku wzorcowe rozwiązania [14]. Jedynie podczas pierwszej Kongregacji Generalnej zapisano podstawowe zasady budowy domów zakonnych i kolegiów: aby były solidne, praktyczne i zdrowe, a równocześnie na tyle skromne żeby nie wyglądały jak pałace [15]. Został wprowadzony także obowiązek akceptacji wszystkich projektów przez urząd centralny, ale podstawową cechą podlegającą ocenie projektów architektonicznych podczas zatwierdzania była odpowiednia dyspozycja funkcjonalna wnętrz.

$\mathrm{Z}$ tego względu należy zastanowić się czy nie można wskazać charakterystycznego rysu architektury jezuickiej na określonym, stosunkowo homogenicznym obszarze. Czy istnieje np. polski styl jezuicki? W jakim stopniu takie lokalne nurty jezuickiej architektury powielają wzorce włoskie (a w szczególności rzymskie), które siłą rzeczy stanowiły punkt odniesienia zarówno dla architektów jak i dla consiliarius aedificiorum - ciała doradczego przy Generale do spraw architektury? Jakie elementy dzieła architektonicznego podlegały najsilniejszym wpływom uwarunkowań lokalnych?

\section{Charakterystyczne rozwiązania architektoniczne kolegiów jezuickich we Włoszech}

Architektura jezuicka narodziła się we Włoszech (prowincja włoska ustanowiona została już w 1552 roku). Tutaj w osobie generała i centralnych urzędów znajdowało się serce zakonu, stąd czerpano wzorce dla wszystkich aspek- 


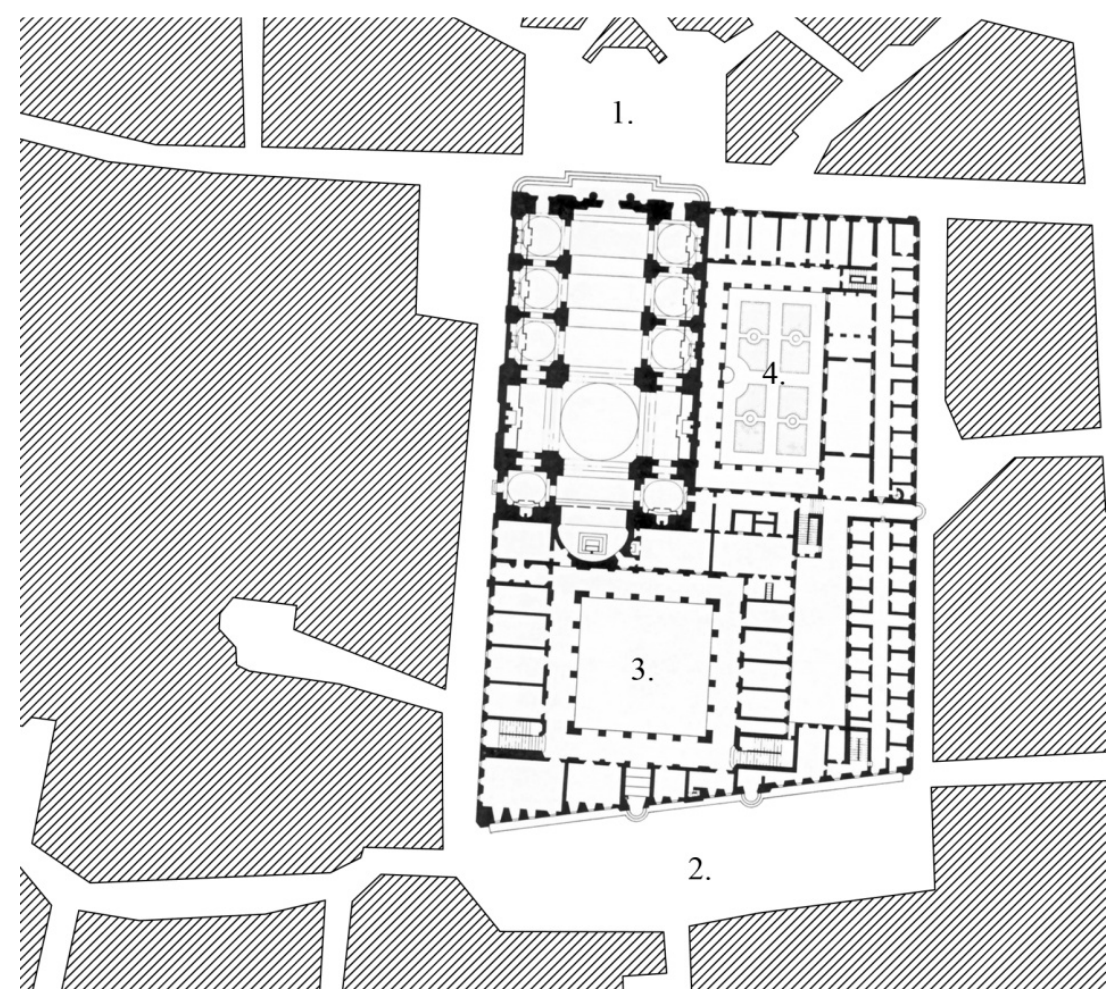

Rys. 1. Rzut Collegio Romano wraz z kościołem Sant'Ignazio z najbliższym otoczeniem, 1. Piazza Sant'Ignazio, 2. Piazza del Collegio, 3. dziedziniec szkoły, 4. ogród na dziedzińcu kolegium właściwego, na podstawie [17]

Fig. 1. Plan of Collegio Romano and Sant'Ignazio church with neighbourhood, 1. Piazza Sant'Ignazio, 2. Piazza del Collegio, 3. school courtyard, 4. garden on convent courtyard, based on [17]

tów działalności na terenie niekiedy bardzo odległych prowincji. Jednocześnie Włochy odgrywały wiodącą rolę w zakresie sztuki i architektury, przez co wypracowane tu rozwiązania powielane były w całej Europie. Mimo tej wiodącej roli same Włochy nie stanowiły jednak jednorodnej tkanki, poprzez odmienne uwarunkowania klimatyczne, polityczne i kulturalne w różnych regionach (od Sycylii po Mediolan) wykształciły się specyficzne rozwiązania architektoniczne [16]. Aby określić zasady kształtowania kolegiów w macierzystej prowincji jezuitów (podzielonej wtórnie na pięć mniejszych jednostek) należy skupić się na pierwszych fundacjach powstających w największych miastach włoskich.

Najbardziej reprezentatywnym budynkiem kolegium jezuickiego było niezaprzeczalnie Collegio Romano (rys. 1) wybudowane w Rzymie dzięki fundacji papieża Grzegorza XIII w latach 1582-1585 według projektu Giuseppe Valeriano. Mimo że uważany był za wzorcowe rozwiązanie przestrzenne kolegium, na 
terenie Włoch nie spotykamy rozwiązań kopiujących bezpośrednio ten ściśle wpasowany w zastany układ urbanistyczny schemat rozplanowania funkcjonalnego. Ze względu na unikalne otoczenie przeznaczonej na kolegium działki dającej możliwość poprzedzenia budynku placem zarówno od północnej strony jak również od południa, po jednej stronie umieszczono kościół natomiast na jego tyłach zlokalizowano budynek szkoły zorganizowany wokół kwadratowego dziedzińca otoczonego szerokimi krużgankami. Kolegium właściwe (dom zakonny), okalające swój wewnętrzny dziedziniec - ogród, wypełniało natomiast pozostałą część działki po stronie wschodniej.

Należy zwrócić uwagę na opracowanie elewacji całego zespołu. Z bogatą w detal, dwukondygnacyjną fasadą kościoła, opracowaną w porządku korynckim oraz ujętą pilastrami jego elewacją boczną zestawione zostały surowe w wyrazie elewacje kolegium właściwego i szkoły. Symetryczna fasada szkoły z wyniesionym o jedną kondygnację bardzo płaskim ryzalitem jest starannie uporządkowana przez regularność rozmieszczenia osi okiennych oraz przez podkreślone odmienną fakturą materiału narożniki i gzymsy. Jej uporządkowana kompozycja organizuje przestrzeń całego placu sprawiając, że zespół kolegium jest niezaprzeczalną dominantą tej przestrzeni miejskiej. Boczne elewacje szkoły i domu zakonnego są natomiast bardzo uproszczone, jedyną ich dekorację stanowią proste, kamienne opaski wokół otworów okiennych.

Z kolei w głównym ośrodku na Sycylii - Palermo powstała (od 1615 do 1668 roku) cała seria rysunków projektowych dla nowego kolegium. Nie różnią się one między sobą zasadniczym ukształtowaniem zespołu. We wszystkich kolejnych projektach zachowana została jednakowa dyspozycja funkcji: na obszernej działce narożnie usytuowany był stosunkowo niewielki kościół, do którego nawy bocznej we wszystkich wariantach przylegał otoczony z czterech stron budynkami szkoły dziedziniec (rys. 2). Kolegium natomiast zajmowało rozległy teren za kościołem i szkołą. Ta podstawowa zasada rozmieszczenia poszczególnych funkcji w zespole wynikała z kształtu i lokalizacji działki, która jednym z krótszych boków przylegała do głównej ulicy miasta. Dlatego we wszystkich projektach w najbardziej reprezentacyjnej pierzei działki usytuowane zostały fasada kościoła oraz szkoły.

Różnice w kolejnych projektach widoczne są przede wszystkim w układzie wnętrz kolegium właściwego. Prezentują one kilka wariantów ukształtowania wewnętrznych dziedzińców oraz usytuowania reprezentacyjnego pomieszczenia refektarza. Ze względu na inne warunki klimatyczne charakterystyczne jest odmienne niż w Rzymie rozwiązanie doświetlenia pomieszczeń. Na Sycylii, gdzie "ucieka się" przed nadmiarem słońca, do części sal szkolnych oraz pomieszczeń mieszkalnych światło dociera jedynie pośrednio przez szerokie krużganki.

W największym ośrodku północnych Włoch - Mediolanie jezuickie kolegium (rys. 3) ufundowane już w 1591 roku budowane było od lat 20-tych do połowy XVII wieku według rysunków Francesco Maria Richini'ego. Było to stosunkowo duże założenie usytuowane na działce (po zlikwidowanym klaszto- 


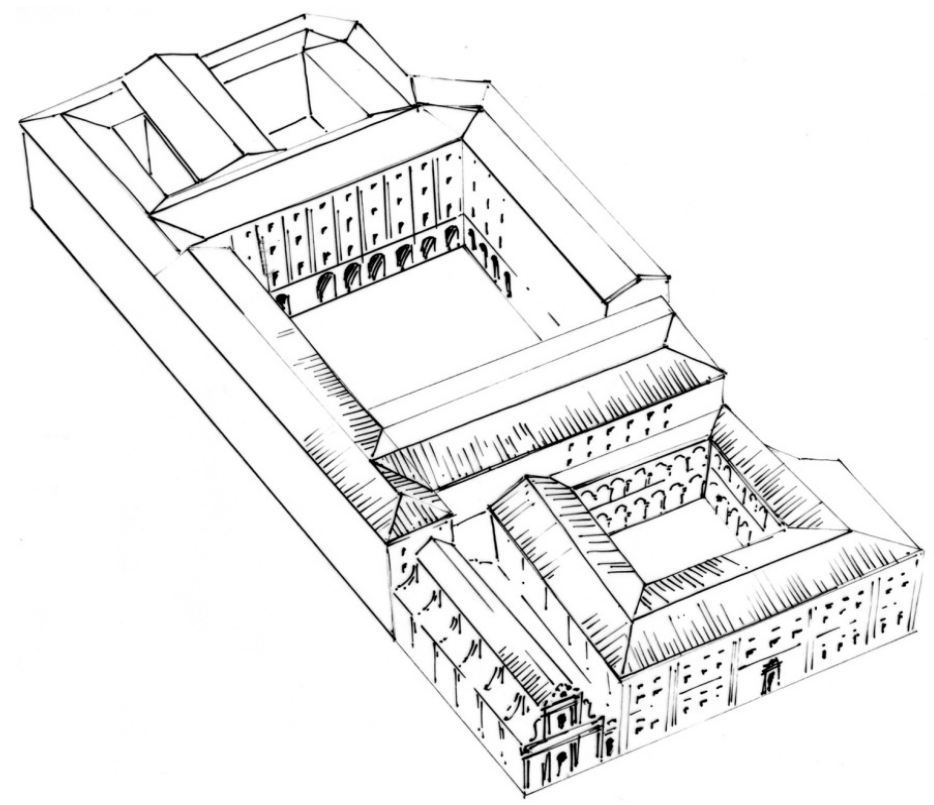

Rys. 2. Rekonstrukcja Collegio Massimo w Palermo, na podstawie [18 i 19]

Fig. 2. Reconstruction of Collegio Massimo in Palermo, based on [18 and 19]

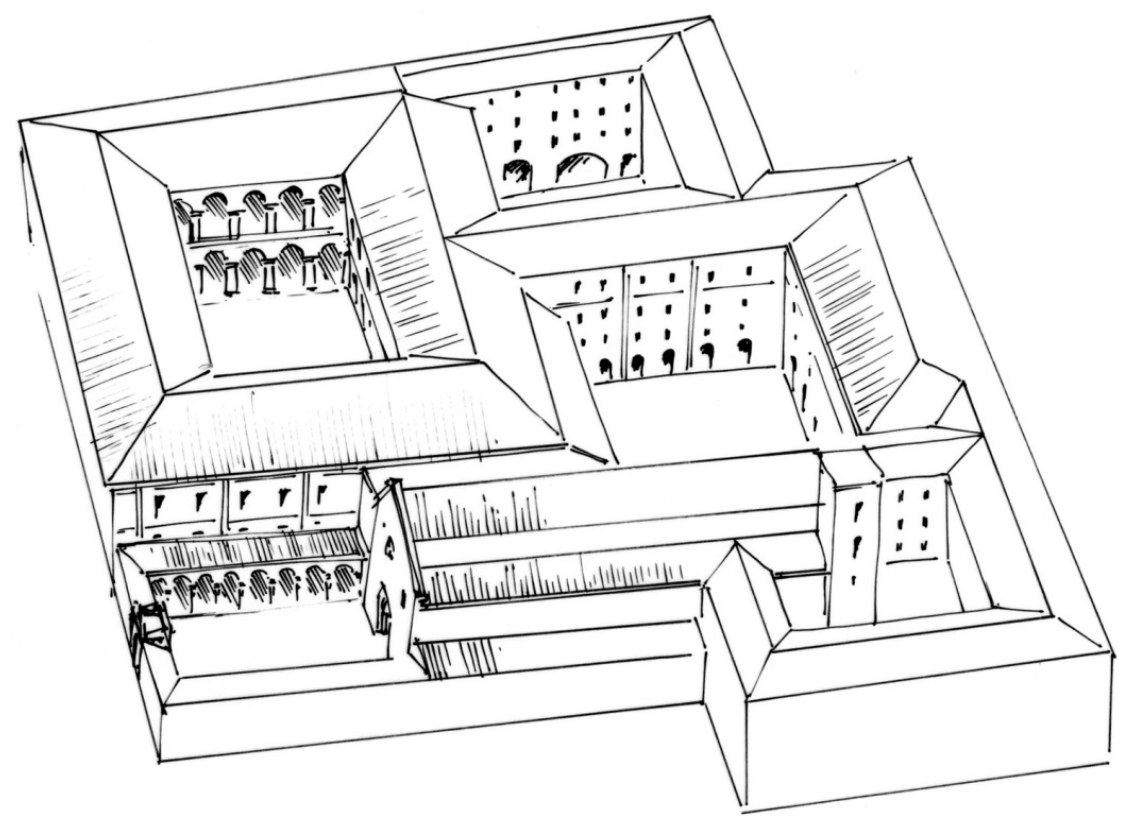

Rys. 3. Rekonstrukcja Collegio di Brera w Mediolanie, na podstawie [18]

Fig. 3. Reconstruction of Collegio di Brera in Milano, based on [18] 
-rze humiliatów) przylegającej do gotyckiego kościoła Santa Maria nella Brera. Kolegium (zwane Collegio di Brera) usytuowane było na skraju średniowiecznego obrysu miasta przy drodze prowadzącej do bramy miejskiej. Przy istniejącej bryle kościoła, o fasadzie wycofanej z pierzei tej ulicy, mediolański architekt zaprojektował kompleks budynków zorganizowanych wokół czterech dziedzińców, a fasadę kościelną poprzedził reprezentacyjnym przeddziedzińcem otoczonym krużgankami. Do budynku szkolnego, otaczającego dziedziniec umieszczony najbliżej głównej ulicy, prowadziło wejście umieszczone w krużgankach przed kościołem. Reprezentacyjne, monumentalne, otwarte na krużganki schody w części szkolnej zajmowały niedoświetlone skrzydło, na którego tyłach znajdowały się pomieszczenia kolegium właściwego.

Ceglane elewacje całego kompleksu ujęte zostały wydatnymi kamiennymi boniami, a otwory okienne uzyskały bogate obramienia z uszakami, gzymsami wspartymi na konsolach oraz naprzemiennie ułożonymi trójkątnymi oraz półowalnymi naczółkami. Bogatsze w tym kompleksie elewacje szkolne i klasztorne należy tłumaczyć brakiem przyciągającej uwagę fasady kościelnej, która wycofana z pierzei ulicznej pozostawiona została w swojej pierwotnej formie.

W Messynie na Sycylii, gdzie powstało pierwsze kolegium jezuickie prowadzące nauczanie w szkole publicznej, budowa docelowego zespołu miała miejsce dopiero w połowie XVII wieku. Wykonane przez neapolitańskiego architekta Giovanniego Gallo projekty zakładały rozplanowane zgodne z ogólnoprzyjętymi wzorcami. Na wydłużonej działce w jednej linii stanęły obok siebie kościół oraz szkoła i kolegium. Budynki ściśle wypełniły należącą do zakonu działkę pozostawiając jedynie wolną przestrzeń w postaci trzech kwadratowych w planie dziedzińców. Wszystkie dziedzińce posiadały bardzo regularną formę, otoczone były sklepionymi krużgankami nawet $\mathrm{w}$ miejscach gdzie do boku dziedzińca nie przylegały żadne pomieszczenia.

Szkoła została umieszczona w pomieszczeniach parteru dziedzińca bliższego kościołowi. Aby zapewnić bezpośrednie połączenie $\mathrm{z}$ przeznaczonymi dla uczniów emporami w kościele, w narożniku szkoły zaprojektowana została klatka schodowa łącząca korytarz szkolny z chórem.

W mniejszych miastach zespoły kolegiów były odpowiednio zredukowane, zazwyczaj zorganizowane wokół dwóch dziedzińców, bądź też czasem jednego wspólnego. W przeważającej części projektów budynek kościoła lokalizowany był w narożniku działki. Rozwiązanie z kościołem umieszczonym centralnie pomiędzy dziedzińcem szkolnym a dziedzińcem kolegium właściwego, które wydawało by się w sposób naturalny rozdziela część publiczną (dostępną dla świeckich) od części klauzurowej, było we Włoszech dość rzadkie.

Wspomniany już wybitny architekt-jezuita: Giuseppe Valeriani SI1 był również między innymi autorem projektu dla niewielkiego kolegium w La Valetcie. W roku 1595 narysował projekt, w którym wszystkie elementy zostały bardzo silnie zredukowane. Obok kościoła umieszczony został tylko jeden dziedziniec (dostępny tylko dla zakonników) przylegający do jego nawy bocznej. Arkadowy 
krużganek obsługiwał tylko jedno skrzydło kolegium, w którym mieściły się pokoje ojców, a pozostałe pomieszczenia dostępne były bezpośrednio z dziedzińca. Szkoła natomiast zajmowała tylko trzy sale na parterze w skrzydle frontowym, z czego jedna większa - narożna pełniła jednocześnie funkcję auli. Dostępna przez portal umieszczony centralnie w elewacji stanowiącej kontynuację frontu kościoła posiadała wyraźnie odseparowaną komunikację (zabudowany korytarz).

Podobnie zredukowany układ miało kolegium w Montepulciano projektu Orazio Grassi'ego SI (który pełnił przez pewien czas urząd consiliarius aedificiorum) zaprojektowane w 1632 roku. Przylegający do bocznej nawy kościoła dziedziniec otaczały od frontu pomieszczenia szkolne (w parterze), a dwa pozostałe skrzydła mieściły kolegium.

Porównując kolegia jezuickie zlokalizowane w różnych częściach Włoch możemy zauważyć, że o ile elewacje zewnętrzne szkoły i kolegium są raczej stonowane, opracowane bez użycia porządków architektonicznych, o tyle dziedziniec szkolny otoczony jest dekoracyjnymi krużgankami wspartymi na kolumnach lub filarach ustawionych zgodnie z zasadą superpozycji porządków. Również klatki schodowe obsługujące część szkolną opracowywane były bardzo starannie, z szerokimi biegami otwartymi na krużganki. We Włoszech ze względu na łagodny klimat cała komunikacja w budynku szkolnym odbywała się na zewnątrz przez krużganki, natomiast w części kolegium dziedzińce posiadały krużganki tylko na poziomie przyziemia (ogrodu), nad którymi biegły zabudowane korytarze lub umieszczano pokoje zakonników. Dlatego też elewacje dziedzińców przynależnych do domu zakonnego są bardzo proste, utrzymane w duchu ubóstwa i (poza delikatnymi podziałami gzymsów) pozbawione dekoracji.

Większe zespoły posiadały osobną przestrzeń rekreacyjną dla uczniów i osobną dla zakonników, a czasem również ogród i podwórze gospodarcze. W zależności od ilości dziedzińców oraz kształtu działki powstawały bardzo różne wzory geometryczne zespołów. W mniejszych miastach, gdzie uposażenie kolegium było często bardzo skromne, wszystkie elementy grupowane były wokół jednego podwórza. Dostęp do dziedzińca w takich przypadkach posiadali tylko zakonnicy co znacząco zmniejszało komfort uczniów. We włoskich kolegiach charakterystyczne jest dążenie do wyraźnego zamknięcia budynkami wewnętrznej przestrzeni, która będzie wizualnie i funkcjonalnie całkowicie odcięta od świata zewnętrznego.

\section{Architekci jezuiccy działający w prowincji polskiej i litewskiej: Włosi i ich uczniowie}

W pierwszym okresie działalności budowlanej jezuitów na terenie Polski i Litwy (od momentu sprowadzenia Towarzystwa Jezusowego w 1564 roku do Potopu Szwedzkiego) olbrzymi wpływ na formę powstających kolegiów mieli Włosi. W tym okresie architektami projektującymi i nadzorującymi budowy jezuickich zespołów budowlanych byli wyłącznie bracia zakonni, a wśród nich najbardziej wyróżniają się postacie włoskich jezuitów (Massima Milanesiego, Józefa 
Brizio, Jana Marii Bernardoniego, Giacoma Briana oraz Benedetta Mollego) wykształconych w sztuce architektury jeszcze na ojczystej ziemi, którzy na prośbę polskich prowincjałów byli delegowani aby nadzorować tutejsze budowy. Pozostali architekci działający w tym okresie to polscy jezuici, którzy pomagając włoskim mistrzom sami zdobyli potrzebne do projektowania umiejętności [20].

Pierwszym przebywającym na terenie Polski architektem jezuickim był Florentczyk - brat Massimo Milanesi (1529-1588). Pomimo że projektował, nie był z wykształcenia architektem, ale pełnił rolę dworzanina na dworze cesarza w Wiedniu. Wstąpił do zakonu jezuitów dopiero w Braniewie w roku 1570. Pierwszymi znanymi projektami jego autorstwa były rysunki kolegium św. Jana w Jarosławiu pochodzace z lat 1574-76. W 1582 roku został przeniesiony do nowego kolegium w Kolożwarze, gdzie sporządził projekt seminarium papieskiego. Wysłany do innego kolegium w Siedmiogrodzie, do Białogrodu, sporządził w 1585 roku projekt dla zespołu budynków z czterema dziedzińcami (z zaadaptowaniem istniejącego kościoła i klasztoru gotyckiego).

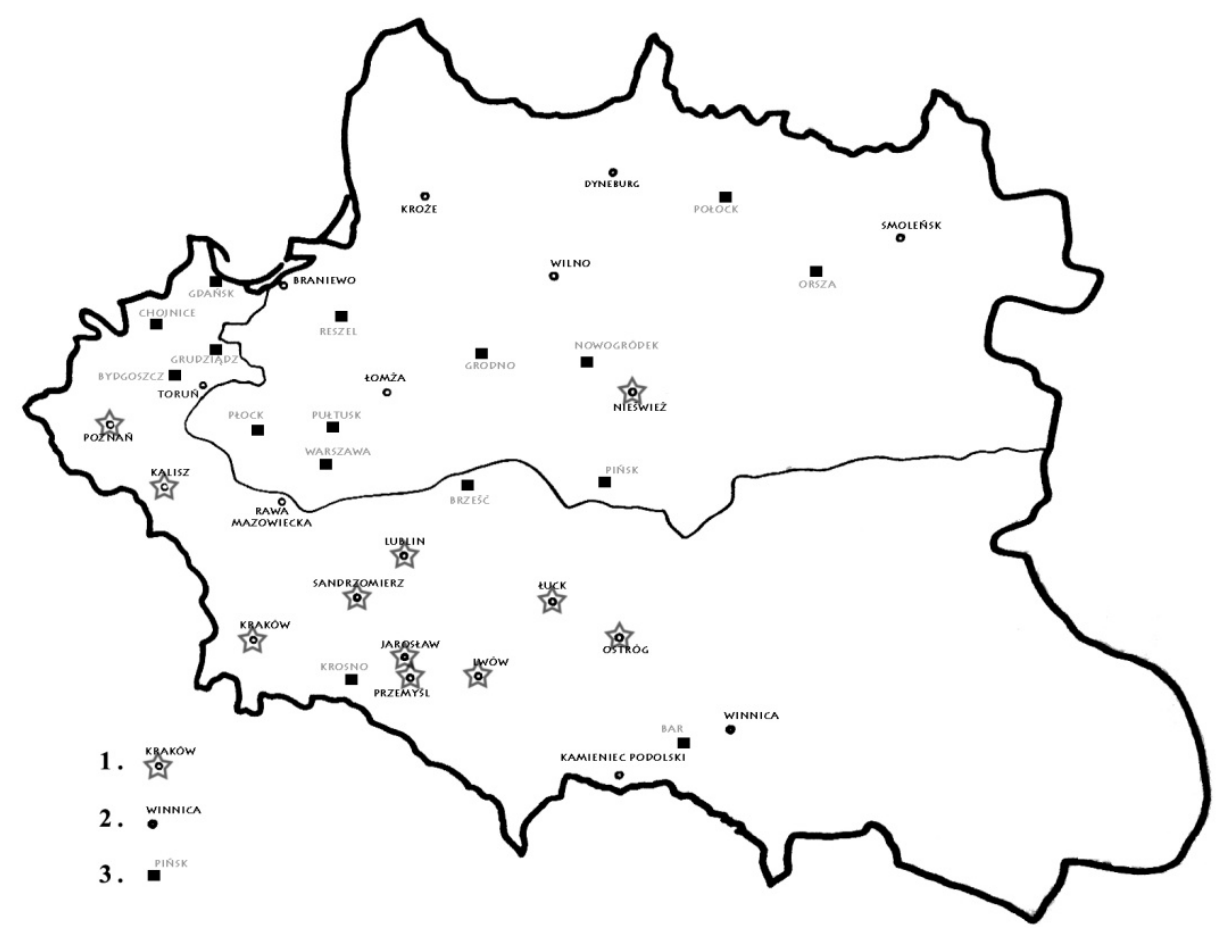

Rys. 4. Rozmieszczenie kolegiów jezuickich w prowincji polskiej i litewskiej - stan około połowy XVII wieku, 1. ośrodki działania włoskich architektów-jezuitów; 2. kolegia zrealizowane przez polskich budowniczych; 3 . kolegia działające w budynkach zaadaptowanych na potrzeby jezuitów lub budynkach tymczasowych, na podstawie [21]

Fig. 4. Map of Jesuit colleges in Polish and Lithuania Province - about half of 17th century, 1. places of Italian Jesuit architects work, 2. colleges built by polish architects, 3. colleges placed in adapted and temporary buildings, based on [21] 
W 1575 roku do Polski przybył kolejny włoski architekt-jezuita Józef Brizio (1533-1604), który pracował wcześniej pod kierunkiem Giovanniego Tristano podczas budów w Rzymie: kolegium, kościoła del'Annunziata i nowicjatu na Kwirynale. W Polsce pracował $\mathrm{w}$ Jarosławiu przy budowie kolegium a następnie kościoła św. Jana. W 1586 roku przebywał w Lublinie nanosząc poprawki na projekt kościoła. W 1591 nadzorował budowę kopuł kościołów w Lublinie i Nieświeżu. W latach 1593-95 wykonał projekty dla zespołów jezuickich w Krakowie: dla rozbudowy domu i kościoła św. Barbary oraz dla domu i kościoła przy ul. Wiślanej, dla domu profesów przy ul. Grodzkiej oraz dla kościoła św. Piotra i Pawła.

Kolejnym włoskim architektem działającym w Rzeczypospolitej był Jan Maria Bernardoni (1541-1605), który będąc doświadczonym architektem zakonnym został wysłany do prowincji polskiej w 1583 roku. Na początku został wysłany do Poznania gdzie sporządził projekt dla kościoła i kolegium. Następnie odesłany do Lublina sporządził plany dla kolegium (przebudowa kamienic) i rozpoczął budowę kościoła za murami miejskimi. W latach 1586-99 Bernardoni przebywał w Nieświeżu, gdzie wybudował kościół Bożego Ciała oraz kolegium. W tym okresie sporządził również projekty dla kościoła i kolegium w Kaliszu. Z Nieświeża został przeniesiony do Krakowa, aby kierować tam (po J. Brizio) budową kościoła św. Piotra i Pawła.

Giacomo Briano (1589-1649), który pochodził z architektonicznej rodziny z Modeny w 1616 r. na własną prośbę został wysłany do prowincji polskiej gdzie brakowało w tym czasie zakonnego architekta. Początkowo pracował przy budowie kościoła w Łucku, następnie został przeniesiony do Lwowa, gdzie sporządził nowe projekty dla rozpoczętego już kościoła, którego budowę następnie nadzorował. W latach 1618-19 czuwał nad budową kolegium w Sandomierzu, po czym przebywał w Krakowie i Lublinie oraz powtórnie w Łucku i Lwowie. W tym okresie wykonał także rysunki dla projektu rozbudowy kościoła w Jarosławiu. W roku 1621, w drodze powrotnej do Włoch, Briano pomierzył plac pod fundację w Przemyślu po czym, już w ojczyźnie, wykonał projekt dla kościoła i kolegium. Po raz kolejny Giacomo Briano został przysłany do Polski na prośbę Anny Alojzy z Ostrogskich Chodkiewiczowej - fundatorki kolegium w Ostrogu. Przy budowie tego kolegium pracował w latach 1630-32. W tym okresie bywał także we Lwowie sporządzając nowy projekt dla kolegium.

Benedetto Molli (1597-1657) wstąpił do zakonu jezuitów już będąc wykształconym w sztuce architektury. Jako zakonny architekt przebywając we Włoszech narysował projekt dla kolegium w Montepulciano oraz kierował budową rzymskiego Collegium Germanicum. Do Polski został wysłany w roku 1633 lub 1634 aby dokończyć prace przy zespole budynków jezuickich w Ostrogu. Podczas swojej obecności w Polsce Molli poza wykonaniem ostatecznego projektu dla kolegium w Ostrogu wykonał rysunki projektowe dla kolegium w Łucku oraz dla rozbudowy kolegium św. Piotra w Krakowie [21].

Patrząc na rozmieszczenie zespołów kolegiów jezuickich zrealizowanych do połowy XVII wieku (rys. 4) widać, iż znaczna ich część wybudowana była przy 
udziale włoskich architektów. Ważny jest także fakt iż prawie wszyscy działający w tym okresie polscy architekci wykształcili się pod okiem przebywających tu włoskich mistrzów. Czy w projektach i realizacjach polskich kolegiów widać bezpośrednie przeniesienie wzorców z Italii, czy może lokalne uwarunkowania wymusiły zmiany pewnych rozwiązań?

\section{Polskie recepcje włoskich wzorców}

Aby odpowiedzieć na nasuwające się pytania należy przeanalizować projekty i realizacje kolegiów z pierwszego okresu działalności budowlanej jezuitów (do Potopu Szwedzkiego), kiedy za znaczną jej część odpowiadali włoscy architekci.

Massimo Milanesi SI projektując w 1585 roku kolegium w Białogrodzie (ówcześnie $\mathrm{w}$ granicach prowincji polskiej) zaproponował bardzo rozbudowany układ z czterema dziedzińcami o rzucie zbliżonym do kwadratów (rys. 5). Część szkolna stykała się narożnikiem z kościołem tworząc razem z nim ramy dla przykolegialnego placu będącego swego rodzaju aneksem głównego rynku miejskiego. Podobnie jak we Włoskich wzorcach Milanesi rozwiązał komunikację na dziedzińcach części klauzurowej (na parterze krużganki, a na piętrze zabudowane korytarze). Inne rozwiązanie zaproponował z kolei dla budynku szkoły: sale lekcyjne usytuowane na parterze dostępne były bezpośrednio $\mathrm{z}$ otwartego dziedzińca, natomiast zamknięta klatka schodowa prowadziła na niewielki wewnętrzny korytarz na piętrze, gdzie architekt umieścił szkolną aulę i salę kongregacji (kaplicę sodalicyjną). Takie rozwiązanie podyktowane było przede wszystkim warunkami klimatycznymi oraz dbałością o lepsze doświetlenie pomieszczeń lekcyjnych. $\mathrm{Na}$ zachowanych rzutach [18] nie widać na zewnętrznych elewacjach, ani na wyższych kondygnacjach wewnętrznych elewacji użycia porządków architektonicznych. Co więcej nie wszystkie otwory okienne zachowują pionowe osie, a na dziedzińcach nie są skorelowane z przęsłami krużganków. Należy więc wnosić, iż były bardzo skromne, a miejscami wręcz nieuporządkowane.

Z kolei w Nieświeżu kolegium wybudowane według projektu Jana Marii Bernardoniego było odsunięte od bryły kościoła. Symetryczny budynek otaczał zamknięty krużgankami dziedziniec domu zakonnego. W parterze jednego ze skrzydeł umieszczone zostały cztery sale lekcyjne dostępne bezpośrednio z wydzielonego szkolnego podwórza. Szkolny dziedziniec podobnie jak w Białogrodzie nie posiadał krużganków ze względu na konieczność doświetlenia sal. Ostatecznie jednak podczas realizacji szkolny dziedziniec zamieniono na gospodarczy, a sale szkolne dostępne były z krużganka głównego dziedzińca. Architekt silnie podkreślił strefę wejścia do kolegium przez umieszczenie jej w wydatnym, wspartym na arkadach, ryzalicie zwieńczonym wieżą zegarową. Takie rozwiązanie frontowej elewacji jest wyraźnym nawiązaniem do rzymskiego wzorca. Bernardoni pomimo braku artykulacji na elewacjach dba o utrzymanie porządku przez rytmiczne ustawienie osi okiennych. Elewacje otrzymały ponadto dekoracyjne szczyty ze spływami wolutowymi [22]. 


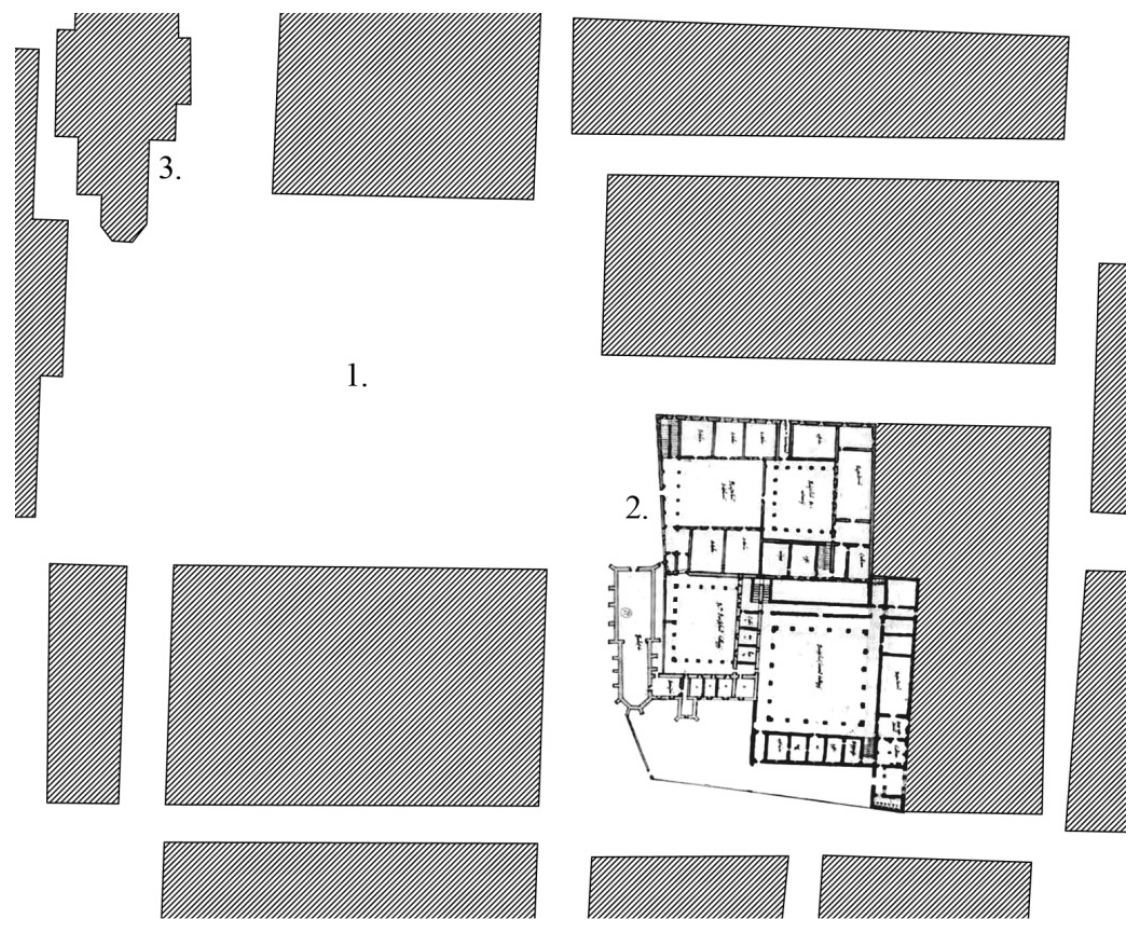

Rys. 5. Projekt kolegium w Białogrodzie wraz z najbliższym otoczeniem, 1. rynek miejski, 2. kolegium jezuickie, 3. fara miejska, na podstawie [18]

Fig. 5. Design of College in Alba Iulia with neighbourhood, 1. town market, 2. Jesuit college, 3. parish church, based on [18]

W kolegium w Przemyślu (rys. 6) architekt Giacomo Briano całkowicie odszedł od stosowania otwartych krużganków. Wszystkie ciągi komunikacyjne poprowadzone zostały wewnętrznymi korytarzami. Umieszczając kościół w najbardziej eksponowanym miejscu działki Briano uzyskał plan zespołu z trzema dziedzińcami oraz podwórzem gospodarczym. Część szkolna przysunięta została do nawy bocznej kościoła, a wejście do niej, ujęte w formę edikuli, znajdowało się tuż obok kościelnej fasady. Z rozrzeźbioną dwukondygnacyjną fasadą kościoła zwieńczoną dwiema wieżami architekt skontrastował bardzo stonowane elewacje zespołu. Ich jedyną dekorację stanowiły portale na tle rytmicznie ustawionych osi okiennych z podkreślonymi za pomocą płaskich gzymsów kordonowych poziomami [23]. Cały zespół tworzył zwartą, masywną bryłę wyróżniającą się w rozdrobnionej tkance miejskiej.

Ten sam architekt zaprojektował zespół kolegium obok istniejącego już kościoła w Lublinie. Ze względu na ukształtowanie działki oraz usytuowanie kościoła poza murami miejskimi zaproponował wyjątkowe rozwiązanie $\mathrm{z}$ wewnętrznym, ale ogólnodostępnym dziedzińcem stanowiącym plac przed fasadą kościoła. Pozo- 


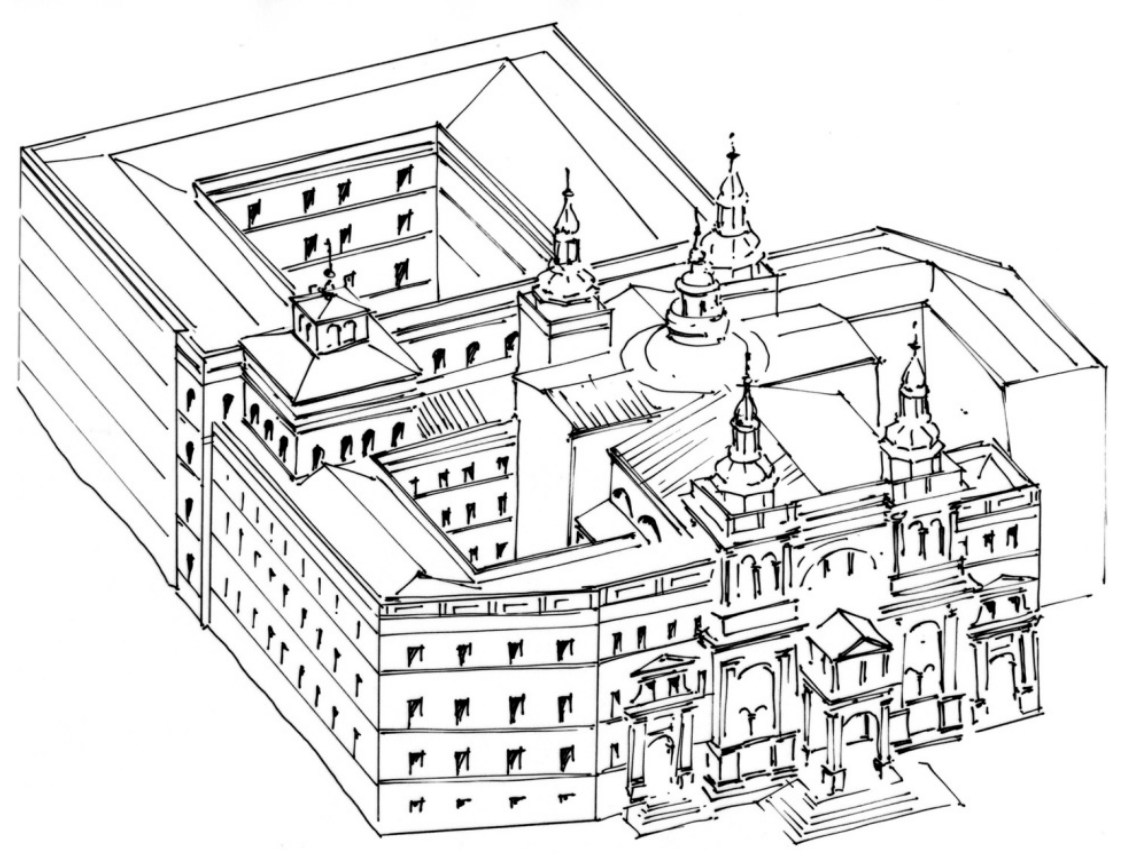

Rys. 6. Wizualizacja projektu Giacoma Briana dla kolegium w Przemyślu, na podstawie [23]

Fig. 6. Visualisation of Giacomo Briano's design for College in Przemysl, based on [23]

stałe budynki zorganizował wokół prostokątnych dziedzińców: szkolnego oraz klauzurowego. Podczas gdy zewnętrzne elewacje Briano pozostawił, podobnie jak w Przemyślu, gładkie i pozbawione bogatej dekoracji, elewacje dziedzińców zrytmizował przez zastosowanie pilastrów o zdwojonych krawędziach [24]. Było to podyktowane po części specyficznym układem zespołu - z kościołem dostępnym z dziedzińca, a nie widocznym i wyeksponowanym w pierzei ulicznej, a po części chęcią poprzedzenia fasady kościelnej reprezentacyjną przestrzenią. W tym kolegium architekt umieścił szkołę z jej wewnętrznym niewielkich rozmiarów dziedzińcem obok bocznej nawy kościoła, natomiast część klauzurową zlokalizował po przeciwnej stronie ogólnodostępnego dziedzińca. Podobnie jak w innych projektach we wszystkich częściach zespołu poprowadził komunikację zamkniętymi korytarzami.

Briano sporządził także projekt dla kolegium we Lwowie. Ze względu na ograniczoną murami miejskimi działkę, wszystkie funkcje zostały tutaj zgrupowane wokół jednego wspólnego dziedzińca. Sale szkolne obsługiwane korytarzami biegnącymi wzdłuż ściany dziedzińca umieszczone zostały w skrzydle frontowym na parterze i na piętrze. Na wyższej kondygnacji zlokalizowano także szkolną aulę. Charakterystyczne jest umieszczenie refektarza oraz znajdującej się nad nim biblioteki. Pomieszczenia te znalazły miejsce w przeciwległym do kościoła narożniku zespołu, w wysuniętym poza obrys ryzalicie. Podobne rozwiązanie widać także na projekcie dla kolegium w Lublinie. 
Ostatnim z włoskich architektów-jezuitów projektujących w prowincji polskiej był Benedykt Molli. Jego projekt dla kolegium w Łucku (przy wybudowanym już kościele) zakładał rozwiązanie przestrzenne $\mathrm{z}$ dwoma dziedzińcami na planie kwadratu (rys. 7). Sale szkolne umieścił na dwóch piętrach, w dwóch skrzydłach otaczających dziedziniec przylegający do nawy bocznej kościoła, który zaprojektował jako otoczony otwartymi krużgankami ${ }^{2}$. Kolegium właściwe umieszczone zostało wokół obszernego, regularnego podwórza umieszczonego za bryłą kościoła. Komunikację w części klauzurowej architekt poprowadził wewnętrznymi korytarzami, a na dziedzińcu zaprojektował ogród o rozbudowanym układzie geometrycznych kwater [25].

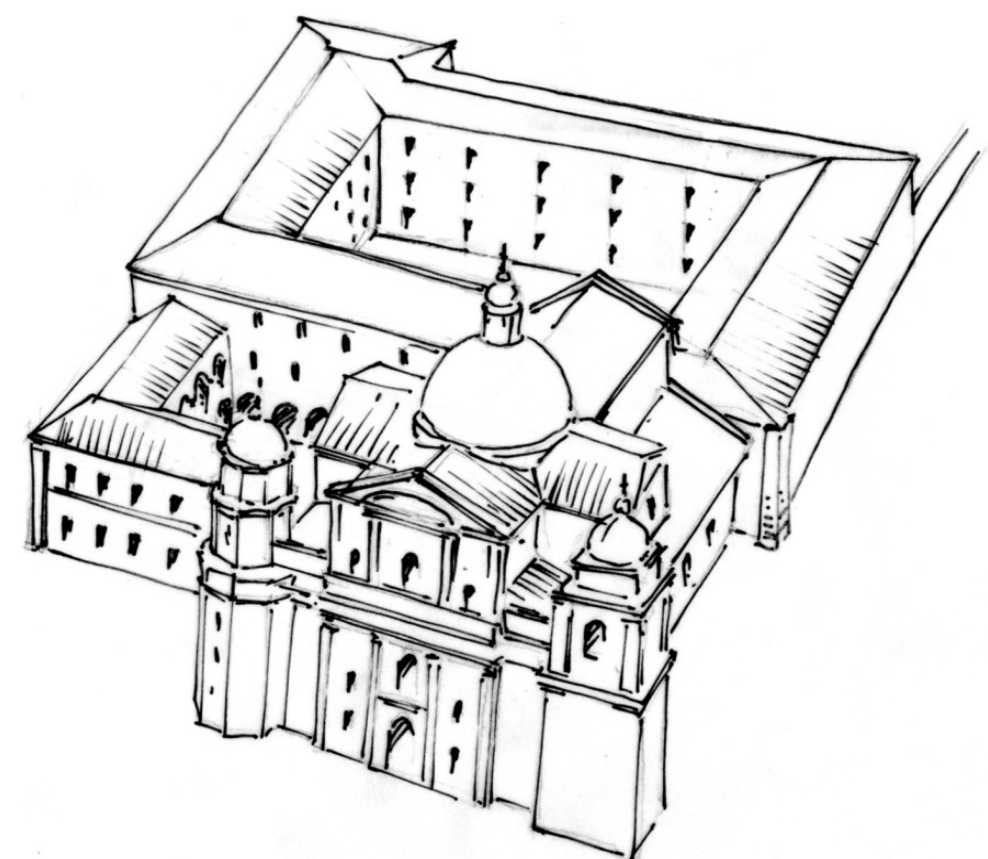

Rys. 7. Wizualizacja projektu Benedetta Mollego dla kolegium w Łucku, na podstawie [18]

Fig. 7. Visualisation of Benedetto Molli’s design for College in Łuck, based on [18]

\section{Podsumowanie}

Powróćmy zatem do postawionego pytania o polski nurt jezuicki. Przyglądając się przywołanym przykładom, a także licznym innym obiektom trzeba zauważyć, że architektura polskich kolegiów w znacznej mierze oparta była na wzorcach

\footnotetext{
${ }^{2}$ Część szkolna nie została jednak zrealizowana w tej formie, tylko zlokalizowano ją w parterze jednego ze skrzydeł domu zakonnego.
} 
włoskich. Zwłaszcza w okresie do Potopu Szwedzkiego preferowane były rozwiązania z budynkami zorganizowanymi wokół zamkniętych dziedzińców z narożnikowo usytuowaną bryłą kościoła, która odcinała się od pozostałych budynków starannością opracowania architektonicznego i rzeźbiarskiego. Trzeba jednak zaznaczyć, że opracowanie elewacji kościołów (poza nielicznymi wyjątkami) było jednak bardziej umiarkowane niż we Włoszech. Szczególnie w miastach uboższych, zwłaszcza na wschodzie, gdzie dominowała prosta, często drewniana architektura, aby nie wywoływać zbytniego rozdźwięku, jezuici projektowali elewacje znacznie skromniejsze od wzorców włoskich. W Polsce opracowanie elewacji kolegium i szkoły było staranne, ale w budownictwie pierwszego okresu działalności Towarzystwa niezbyt bogate. Otwory okienne tylko w części obiektów uzyskały obramienia, a podziały płaszczyzny ścian zaznaczane były (jeśli w ogóle) w sposób bardzo delikatny. Podobnie jak w Italii staranne opracowanie zyskują portale wejściowe do szkoły i kolegium, które skontrastowane z gładką ścianą stanowią silne akcenty kompozycyjne.

Najbardziej widoczne są zmiany wzorców wynikające z przystosowania do odmiennych warunków klimatycznych. Otwarte krużganki nie sprawdzały się w długim okresie jesienno-zimowym, a niewielka ilość światła docierająca w tym okresie do okien również przemawiała za ich likwidacją. Powodowało to rezygnację z reprezentacyjnego arkadowego dziedzińca szkolnego i starannie opracowanej głównej klatki schodowej (która w Polsce najczęściej była zamknięta i przez to o wiele mniej eksponowana). Podyktowane było to również względami klimatycznymi: we Włoszech ten "galowy" dziedziniec mógł służyć różnym publicznym przedsięwzięciom: przedstawieniom, misteriom czy deklamacjom, natomiast w Polsce warunki klimatyczne nie pozwalały przez większość roku na organizację takich przedsięwzięć na otwartym powietrzu i były one organizowane we wnętrzach: w auli szkolnej lub we wnętrzu kościoła. Mimo że początkowo, bezpośrednio kopiując rozwiązania włoskie, projektanci proponowali otwarte krużganki, były one w kolejnych projektach, lub już w trakcie użytkowania obiektu wtórnie zamurowywane ze względu na ich niefunkcjonalność.

Bardzo charakterystycznym rozwiązaniem stosowanym w prowincji polskiej jest specjalne miejsce jakie uzyskał refektarz oraz umieszczona nad nim biblioteka. Po części również ze względów oświetleniowych pomieszczenia te umieszczane były w delikatnym ryzalicie (najczęściej na narożniku budynku), aby przez lepsze doświetlenie uzyskały bardziej reprezentacyjny charakter.

Jak widać wpływom lokalnym przede wszystkim podlegała dekoracja i opracowanie elewacji. Układ funkcjonalny natomiast, zachowując ogólne zasady rozplanowania, zawsze dostosowany był do miejsca, ze względu na konieczność wpasowania się w istniejącą już, skomplikowaną tkankę miasta. Różnice w przestrzennym rozmieszczeniu elementów wynikają przede wszystkim z kształtu działki jaką dysponował zakon oraz z jej usytuowania w strukturze miasta, a nie $\mathrm{z}$ lokalnych preferencji.

W polskich kolegiach struktura wewnętrzna stosowana we włoskich zespołach jezuickich uległa bardzo niewielkim modyfikacjom. Również szata styli- 
styczna (mimo że często skromniejsza) była silnie związana z wzorcami włoskimi. Takie wyraźne przywiązanie do wzorcowych, rzymskich rozwiązań niewątpliwie związane było $\mathrm{z}$ silną obecnością $\mathrm{w}$ prowincji polskiej architektów pochodzących z Italii, którzy nie tylko sami projektowali i wznosili w Polsce kolegia, ale także wychowywali kolejne pokolenia polskich architektów-jezuitów.

\section{Literatura}

[1] Paszenda J.: Losy tak zwanego stylu jezuickiego, Biuletyn Historii Sztuki, Tom 62, Numer 1/2, 2000, s. 163-174.

[2] Dainville de F.; La Légende du style jésuite, Etudes, n² 287, 1955, pp. 3-16.

[3] Christ Y.: Le style jesuite n'existe pas, Jardin des arts, ${ }^{\circ}$ 86, 1962, pp. 44-49.

[4] Pirri P.: Giovanni Tristano e i promordi della architettura gesuitica, Institutum Historicum Societatis Iesu, Rzym 1955.

[5] Moisy P.: Les églises des jésuites de l'acière assistance de France, Institutum Historicum Societatis Iesu, Rzym 1958.

[6] Vallery-Radot J.: Le recueil de plans d'édifices de la Compagnie de Jésus conservé à la Bibliothèqne nationale de Paris, Institutum Historicum Societatis Iesu, Rzym 1960.

[7] Bösel R.: Jesuitenarchitektur in Italien (1540-1773), I. Die Baudenkmäler der römischen und der neapolitanischen Ordensprovinz, II. Die Baudenkmäler der mailändischen Ordensprovinz, Österreichischen Akademie der Wissenschaften, Wien 1985-2007.

[8] Bencivenni M.: L'architettura della Compagnia di Gesu in Toscana, Alinea, Firenze 1996.

[9] Paszenda J.: Budowle jezuickie w PolsceXVI-XVIII w., tom 1-5, Wyższa Szkoła Filozoficzno-Pedagogiczna „Ignatianum” - Wydawnictwo WAM, Kraków 1999-2013.

[10] Bailey G.: Le style jesuite n'existe pas: Jesuit Corporate Culture and the Visual Arts, The Jesuits: cultures, sciences, and the arts, 1540-1773, Vol. 1, University of Toronto Press, Toronto 1999.

[11] Levy E.: Propaganda and the Jesuit Baroque, University of California Press, Berkeley 2004.

[12] Marino A.: L'idea di tradizione e il concetto di modernità nell'architettura della Compagnia di Gesù , L' architettura della Compagnia di Gesù in Italia. XVI-XVIII secolo, Centro Culturale S. Fedele, Milano 1992, pp. 53-56.

[13] Galantowicz B.: Rozwiązania urbanistyczne barokowych zespołów budowli jezuickich na Śląsku a problem akomodacji w działalności misyjnej jezuitów, Oficyna Wydawnicza Politechniki Wrocławskiej, Wrocław 1997.

[14] Smith J.C.: Sensuous Worship: Jesuits and the Art of the Early Catholic Reformation in Germany, Princeton University Press, Princeton 2002.

[15] O’Malley J.: Pierwsi jezuici, Wydawnictwo WAM, Kraków 1999.

[16] Bosel R.: Episodi emergenti dell'architettura gesuitica in Italia, La arquitectura jesuítica. Actas del Simposio Internacional, Institucion Fernando el catolico (C.S.I.C.), Zaragoza 2012, pp. 71-89. 
[17] Patetta L., Balestreri I., Coscarella C., Zocchi D.: L'architettura della Compagnia di Gesu in Italia XVI-XVIII sec., Grafo, Brescia 1990.

[18] http://gallica.bnf.fr (dostęp 05.10.2016 r.).

[19] https://www.maremagnum.com/stampe/palermo-pianta-della-citta-di-palermo/ 130083158 (dostęp 05.10.2016 r.).

[20] Paszenda J.: Architekci jezuiccy w Polsce, Praxis atque theoria. Studia ofiarowane profesorowi Adamowi Małkiewiczowi, IHS UJ, Kraków 2006, s. 245-253.

[21] Poplatek J., Paszenda J.: Słownik jezuitów artystów, Wydawnictwo WAM, Kraków 1972.

[22] Paszenda J.: Kościół Bożego Ciała (pojezuicki) w Nieświeżu, Kwartalnik Architektury i Urbanistyki, Tom 21, Nr 3, 1976, s. 195-216.

[23] Betlej A.: Projekty Kościoła Jezuitów w Przemyślu. Uwagi na temat rysunków Giacomo Briano ze zbiorów The Getty Research Institute, Sprawozdania z czynności i posiedzeń PAU, 65, 2001, s. 131-133.

[24] Paszenda J.: Lubelskie projekty Michała Hintza i Jakuba Briano, Kwartalnik Architektury i Urbanistyki, Tom 17, Nr 1, 1972, s. 41-58.

[25] Paszenda J.: Dzieje budowy kościoła i Kolegium Jezuitów w Łucku według źródeł jezuickich, Kwartalnik Architektury i Urbanistyki, Tom 45, Nr 1, 2000, s. 34-44.

\section{ARCHITECTURE OF JESUIT COLLEGES IN ITALY AND POLAND - ATTEMPT OF COMPARISON}

\section{S u m m a r y}

At the end of 16th century, when the Society of Jesus started their activity in Poland, the same they started to build convent houses. Colleges, founded by bishops and aristocrats, were independent units in which Jesuits were running their schools.

The first builders of those colleges were Italian Jesuits skilled in architecture. Formed by Italian architecture paradigm, they used solutions they knew. But according to the rule of accommodation to local needs and conditions, they adjusted their designs to local circumstances to assure their proper functioning there.

Despite clearly visible similarities, especially in general planning the elements of the complex, in Polish transpositions of Italian models, their specific features are evident. Comparing functional and architectonic solutions applied in colleges in Poland and Italy allows to determine how strong the local influence on basic models was. Different climate conditions resulted in separating communications from the yards and also in other way of using the latter. And also poorer neighbourhood (specially in smaller towns) lead to the simpler and less decorative facades. Last but not least it should be emphasized the necessity to conform to the specific situation: the shape of the plot and the shape of surrounding buildings by using existing scenic axes and connections. The above makes every Jesuit complex one-off and shows the philosophy of Society of Jesus in the fullest way.

Keywords: Society of Jesus, Jesuit architects, Jesuit style, Jesuit schools

Przestano do redakcji: $15.10 .2016 r$.

Przyjęto do druku: 30.06 .2017 r. 